\title{
Application of Biophilic Patterns in Health Care Environments to Enhance Healing
}

\author{
Rania El Messeidy \\ Lecturer, Department of Architecture, Faculty of Engineering, October University for \\ Modern Sciences and Arts (MSA) University, $6^{\text {th }}$ of October, Cairo, Egypt \\ rhamdi@msa.eun.eg rania_h2000@yahoo.com
}

\begin{abstract}
As our lives become more civilized, our association with nature has decreased. In any case, improvements in innovation and new frames of mind towards design, just as some exceptionally persuading researches, are prompting positive change, yet in some pilot projects. As the world is keeping on urbanizing; Biophilic design has an important role in establishing a linkage between nature and constructed environment. Biophilic design can diminish pressure, help human to be more creative and feel comfort. It enhances healing and improve well-being. Biophilic design has demonstrated its benefits in various context; such as improving working environment, encouraging children to learn and enhance health. This study focuses on the importance of biophilic design in healthcare environments. The study intends to define biophilic design through a literature review, highlights its effects on human being and its relevance to healing process. The theoretical part is followed by the investigation of an international case study of biophilic design for hospitals in terms of biophilic patterns, then the study will proceed in applying the biophilic patterns on another case study. The paper therefore concludes the importance of biophilic design in enhancing healing, and the possibility of incorporating biophilic design in health care environments providing innovative solutions to integrate nature in hospitals environments.
\end{abstract}

Keywords: Biophilic design, Biophilic patterns, Human being, Hospitals, Healing.

\section{Introduction}

Biophilic design has been appeared early in historic structures and places in form of consisted natural themes. Before and after the industrial revolution, people were connected to nature and living in an agriculture atmosphere. In the 19th Century; the urban population increased and the concern with health and sanitation increased. It became very important to enlarge the green areas such as public parks as a kind of health improvement and to reduce stress of urban living (1). Architectural design has always tends to separate between buildings and landscape and treats them as two separate issues which by sequences affects in a negative way the environment and humans, in addition, the quality of the built environment 
in contemporary cities has emphasized the isolation of individuals from the experience of natural systems and processes (2). Biophilic design goes for making solid associations among nature and constructed environment, and has demonstrated advantages in terms of improving productivity, health and children leaning.

(WHO) the World Health Organization points out many factors that, if improved can help make communities healthier places to live, learn, work, and play. Three main aspects are emphasized: health outcomes, health factors, and policies and programs. (3)

This study focuses on the importance of biophilic design in healthcare environments. The study intends to define biophilic design through a literature review, highlights its effects on human being and its relevance to healing process. The theoretical part is followed by the investigation of an international case study of biophilic design for hospitals in terms of biophilic patterns, then the study will proceed in applying the biophilic patterns on another case study. The paper therefore concludes the importance of biophilic design in enhancing healing, and the possibility of incorporating biophilic design in health care environments providing innovative solutions to integrate nature in hospitals environments.

\section{Biophilic Design: Connection to Nature}

Cravings for natural light are called "photophilia" correctly, and for natural environments "topofilia". However, it is useful to include these physiological responses under the broader term biophilia (4). The term Biophilia has been utilized by Erich Fromm (5), in "The Anatomy of Human Destructiveness" (1973), which portrayed Biophilia as "the enthusiastic love of life and of all that is alive". The term was later utilized by Edward O. Wilson (6), in his work Biophilia (1984), which suggested that the propensity of people to concentrate on and to subsidiary with nature and other living things has to a limited extent, a hereditary premise (7). Biophilia is one of three theories that help elucidate the interdependency of human health and wellbeing and the natural world. Biophilia explores how people's instinctive affinity for the natural world drives them to directly interact with nature, and how activities like walking in a forest ravine, swimming or fishing in a free-flowing stream, or hiking and camping on a mountaintop, can confer a range of vital physical and mental benefits (3).

Biophilic design portrays a strategy that originates from the term biophilia. Biophilic design, depends on the endeavor to exchange the intrinsic tendency of people towards natural systems and processes in the urban project. Thus, biophilic design is not just a vegetation way in a place or space but it is a strategic implementation providing a specific pattern and a visual connection to nature (6). 
Stephen R. Kellert (8), defined biophilic design as "an innovative approach that emphasizes the necessity of maintaining, enhancing, and restoring the beneficial experience of nature in the built environment" (9). Kellert has recognized two fundamental elements of biophilic plan: the natural or naturalistic measurements (the types of the assembled condition that refer in a direct, indirect or in a symbolic way to nature) and vernacular measurement (when the urban environment or landscape refers to a specific cultural area (10).

As indicated by Kellert, the two measurements are connected to six biophilic plan components (ecological highlights; regular shape and structures; characteristic patterns and procedures; light and space; place-based connections; advanced human instinct connections) which are thusly found in more than 70 biophilic design attributes (2).

A study of 14 types of Biophilic has organized this approach into three broad categories: "Nature in the Space" in which designs involve direct contact with nature or common frameworks. "Normal Analogues" in which designs identify with portrayals and deliberations of nature. "Nature of the Space" in which designs are spatial conditions gotten from nature. In this manner Biophilic design can be sorted out into three classifications "Nature in the Space, Normal Analogues, and Nature of the Space" giving a structure to understand and empower mindful joining of an assorted variety of techniques into the constructed environment (11).

Based on a recent study, biophilic design patterns could be classified into nature inside space, presenting nature, and spatial characteristics, totaling nine detailed patterns (12).

Table 1. Biophilic Design Patterns. Ref. (1); 1 r)

\begin{tabular}{|c|c|c|}
\hline \multicolumn{2}{|c|}{ Biophilic Design Pattern } & Definition \\
\hline \multirow{4}{*}{$\begin{array}{l}\text { Nature inside space: } \\
\text { It represents the } \\
\text { immediate nearness of } \\
\text { nature in a space or } \\
\text { place, such as } \\
\text { vegetation, water and, } \\
\text { fragrances. }\end{array}$} & $\begin{array}{l}\text { Visual Connection } \\
\text { with Nature }\end{array}$ & $\begin{array}{l}\text { Providing views of indoor and outdoor nature, } \\
\text { ecosystem, and changes. }\end{array}$ \\
\hline & $\begin{array}{l}\text { Non-Visual } \\
\text { Connection with } \\
\text { Nature }\end{array}$ & $\begin{array}{l}\text { Providing auditory, olfactory, tactile, and } \\
\text { gustatory stimulations from nature, ecosystem, } \\
\text { and their changes. }\end{array}$ \\
\hline & $\begin{array}{l}\text { Dynamic and } \\
\text { Diffuse Light }\end{array}$ & $\begin{array}{l}\text { Providing a vibrant nature-like environment } \\
\text { through various lights and shadows. }\end{array}$ \\
\hline & $\begin{array}{l}\text { Connection with } \\
\text { Natural Systems }\end{array}$ & $\begin{array}{l}\text { Providing an environment to feel the healthy } \\
\text { changes of nature such as seasonal variations. }\end{array}$ \\
\hline \multirow{3}{*}{$\begin{array}{l}\text { Presenting nature: } \\
\text { It tends to natural, } \\
\text { non-living and } \\
\text { aberrant inspirations of } \\
\text { nature, such as articles, } \\
\text { materials, and, } \\
\text { furniture. }\end{array}$} & $\begin{array}{l}\text { Biomorphic Forms } \\
\text { and Patterns }\end{array}$ & $\begin{array}{l}\text { Providing symbolism of forms, patterns, } \\
\text { materials, and ratios observed in nature }\end{array}$ \\
\hline & $\begin{array}{l}\text { Material } \\
\text { Connection with } \\
\text { Nature }\end{array}$ & $\begin{array}{l}\text { Material connection with nature, by } \\
\text { minimizing processing and presenting } \\
\text { ecological characteristics of the region. }\end{array}$ \\
\hline & $\begin{array}{l}\text { Complexity and } \\
\text { Order }\end{array}$ & $\begin{array}{l}\text { Providing an environment to receive various } \\
\text { kinds of sensory information of nature } \\
\text { focusing on the hierarchy of natural elements. }\end{array}$ \\
\hline $\begin{array}{l}\text { Spatial } \\
\text { characteristics: }\end{array}$ & Prospect & $\begin{array}{l}\text { Providing an open environment to observe, } \\
\text { view, and monitor the surrounding }\end{array}$ \\
\hline
\end{tabular}




\begin{tabular}{|c|c|c|}
\hline \multirow{2}{*}{$\begin{array}{l}\text { It tends to spatial } \\
\text { designs in nature, such } \\
\text { as attention to danger } \\
\text { or something } \\
\text { ambiguous, dark } \\
\text { perspectives and } \\
\text { exquisite minutes. }\end{array}$} & & environment. \\
\hline & Refuge & $\begin{array}{l}\text { Providing a space that provides a sense of } \\
\text { security of being protected from environmental } \\
\text { changes. }\end{array}$ \\
\hline
\end{tabular}

\section{Biophilic design patterns and Human biological responses.}

Table 2 shows a summary of research findings about biophilic design patterns and human biological responses (11). The table shows that there are positive effects on stress relief, cognitive skills, and sensitivity, atmosphere, and preference. (12).

Table 2. Biophilic design patterns and Human biological responses. Ref. (12)

\begin{tabular}{|c|c|c|c|}
\hline \multirow[b]{2}{*}{$\begin{array}{c}\text { Biophilic } \\
\text { Design Pattern }\end{array}$} & \multicolumn{3}{|c|}{ Biological Response } \\
\hline & Stress Relief & Cognitive Skills & $\begin{array}{c}\text { Sensitivity, } \\
\text { Atmosphere, and } \\
\text { Preference }\end{array}$ \\
\hline $\begin{array}{l}\text { Visual } \\
\text { Connection with } \\
\text { Nature } \\
\end{array}$ & $\begin{array}{lr}\text { Lowering } & \text { blood } \\
\text { pressure } & \text { and } \\
\text { decreasing heart rate. }\end{array}$ & $\begin{array}{lr}\begin{array}{l}\text { Increasing } \\
\text { engagement } \\
\text { concentration. }\end{array} & \begin{array}{r}\text { work } \\
\text { and }\end{array} \\
\end{array}$ & $\begin{array}{l}\text { Positive effect } \\
\text { spatial preference. }\end{array}$ \\
\hline $\begin{array}{l}\text { Non-Visual } \\
\text { Connection with } \\
\text { Nature }\end{array}$ & $\begin{array}{l}\text { Lowering systolic } \\
\text { blood pressure and } \\
\text { relieving stress. }\end{array}$ & $\begin{array}{l}\text { Positive effect on } \\
\text { cognitive skills. }\end{array}$ & $\begin{array}{lr}\text { Promoting } & \text { mental } \\
\text { health } & \text { and } \\
\text { psychological } & \\
\text { composure. } & \\
\end{array}$ \\
\hline $\begin{array}{l}\text { Dynamic and } \\
\text { Diffuse Light }\end{array}$ & $\begin{array}{lr}\text { Increasing } & \text { comfort, } \\
\text { happiness, } & \text { and } \\
\text { productivity. } & \\
\end{array}$ & $\begin{array}{l}\text { Positive effect on } \\
\text { increased concentration. }\end{array}$ & $\begin{array}{lr}\text { Improving } & \text { spatial } \\
\text { preference } & \text { and } \\
\text { perception. } & \\
\end{array}$ \\
\hline $\begin{array}{l}\text { Connection with } \\
\text { Natural } \\
\text { Systems }\end{array}$ & Relieving stress/ & & $\begin{array}{lr}\text { Changing } & \text { the } \\
\text { perception } & \text { about } \\
\text { environment } & \text { and } \\
\text { promoting health. } & \end{array}$ \\
\hline $\begin{array}{l}\text { Biomorphic } \\
\text { Forms and } \\
\text { Patterns }\end{array}$ & & & $\begin{array}{l}\text { Increasing preference } \\
\text { for view. }\end{array}$ \\
\hline $\begin{array}{l}\text { Material } \\
\text { Connection with } \\
\text { Nature }\end{array}$ & & $\begin{array}{l}\text { Lowering diastolic } \\
\text { pressure. }\end{array}$ & $\begin{array}{l}\text { Promoting relaxed } \\
\text { feeling. }\end{array}$ \\
\hline $\begin{array}{l}\text { Complexity and } \\
\text { Order }\end{array}$ & $\begin{array}{l}\text { Relieving } \\
\text { psychological stress. }\end{array}$ & 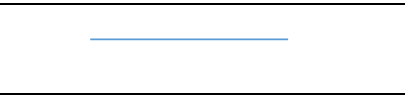 & $\begin{array}{l}\text { Increasing preference } \\
\text { for view. }\end{array}$ \\
\hline Prospect & Relieving stress. & $\begin{array}{l}\text { Reducing boredom and } \\
\text { fatigue. }\end{array}$ & $\begin{array}{l}\text { Improving ability to } \\
\text { perceive comfort and } \\
\text { safety. }\end{array}$ \\
\hline Refuge & & $\begin{array}{l}\text { Improving concentration } \\
\text { and ability to perceive } \\
\text { safety. }\end{array}$ & $\begin{array}{l}\text { Improving ability to } \\
\text { perceive stability and } \\
\text { safety. }\end{array}$ \\
\hline
\end{tabular}




\section{Biophilic Design and Healing}

The best biophilic design - design that adequately wipes out pressure and uneasiness from the built environment - is accomplished by keeping up keen associations with nature.

As per (8) biophilic design is not just a tool to make a building green or make it more beautiful by using trees and shrubs. However, it is about bringing nature in human's places, and the natural world's place in human society.

As human beings, it is very important to live in connection with nature, the living environment should introduce this living way. As for architects; they are facing a critical task which is incorporating healing strategies in their designs, trying to reach the biophilic effect. This kind of architecture has been introduced in previous centuries. But the mechanical and industrial approach made architects ignore human responses to the constructed environment after a while (4).

In 1839, the "healing powers of nature" was mentioned by Lexicon Medicum, contending that numerous sicknesses could be relieved by focusing on air, sustenance, comfort, physical movement, and positive feelings. Many researches confirmed these assumptions and it was supported in the 20th century by Ulrich's research in 1980, about the recovery of patients in connection with landscape, to confirm that the nature could be beneficial in healing process and in hospitals environments. Ulrich tested the impact of nature and landscape view upon the recovery time of patients who have made a surgery. The result shows that the patients provided with an outdoor view released a number of day minimum than who did not have a view in their room. Similar researches have proved that natural daylight has a positive influence on patient recovery. The same finding was by Texas A\&M University as they found that natural elements in landscape makes difference. Heerwagen and Orians found that workers use photos and posters of natural elements more than others when their offices are windowless (1).

Different studies found that the internal landscape in hospitals improve patients' health and a percentage of $95 \%$ of patients and visitors reported positive levels of mood and happiness. Also, the existing of green roofs and greenery in rooms diminish the level of pain and improve the psychological response of patients to treatment. A few investigations have likewise exhibited that the utilization of normal materials improves the patients' impression of ecological quality and their recuperation from the disease (2). Also, regular light effects affect patients experiencing chemotherapy. Therefore, it was considered that the nature was therapeutic and has the capability to influence the health of people and help patients to recover. Moreover, researches supported the benefits of what the nature could provide to the building through biophilic design; whether through architectural solutions or through using biophilic design in term of interior spaces. 


\section{Investigation of International Example: Östra Psychiatry Hospital,} White Architects, Göteborg, Sweden, 2006 (White Architects)

The Östra Hospital area is 18,000 square meters. The healthcare building win "Forum's Healthcare Building Award 2007". Throughout the design process, White Architects had a unique vision of design using architecture as a tool to alleviate suffering and promote the recovery of mental health. The architects carefully observed every aspect of the patient's experience, respecting the strict safety and protection standards required for a psychic installation. The white architects were aware of the importance of placing places in a facility where patients can have long periods of time.

The "complexity and order" have benefited from the repetition within the spaces to support the sense of belonging. Through the superposition of social spaces, from the private to semi-private, to the public, patients can participate in a variety of social environments according to their own preferences. The hospital also has "Visual Connection with Nature, Dynamic and Diffused Light, and Refuge", all of which combine to create a relaxing and healing environment (13).

Figure 1. Architecture on the inside of life. Ref. (14)

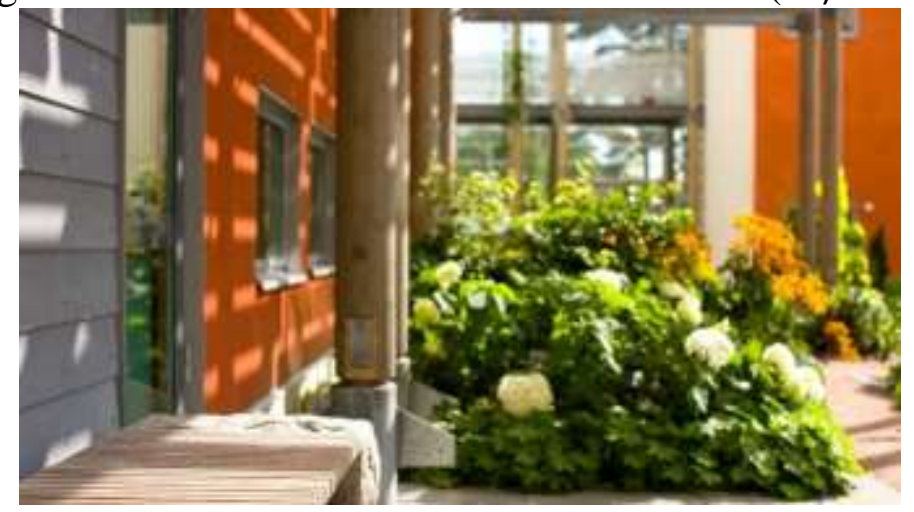

The design of Östra Hospital Suite creates a free and open environment that destroys the preconceived notions of traditional institutional environments. Evidence-based research suggests that successful care requires a gradual increase in the personal space of patients from their room, to the park, to a wider public domain and, finally, to return to outside life. The design aimed to create a "free and open" atmosphere, to avoid any association with force and power (14).

Figure 2. The design aimed to create a "free and open" atmosphere, to avoid any associations with force and power. Ref. (14) 


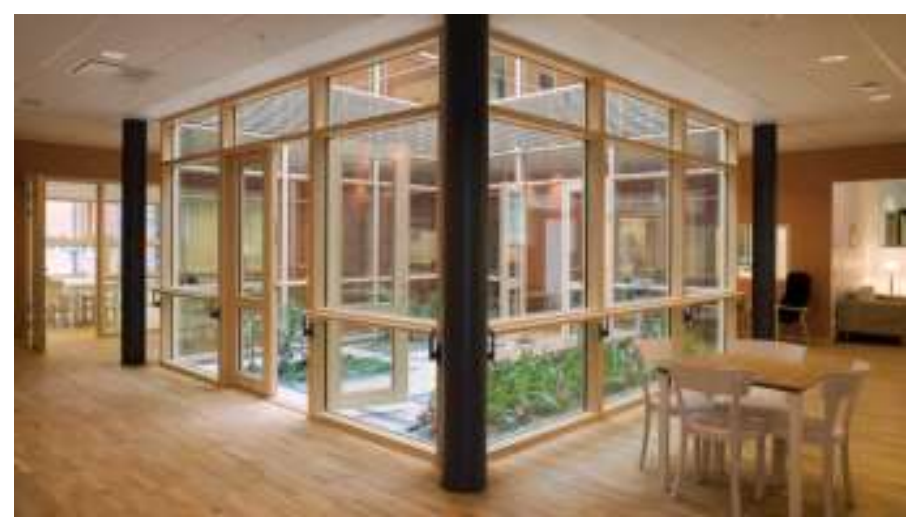

Östra Hospital is a "corridor-free ward" that offers patients, medical staff, family members and visitors the opportunity to take advantage of a warm environment, with delicate social terraces, from separate rooms to seating areas inspired by "Swedish veranda". At the heart of the suite are the areas for living, the kitchen and other common spaces enclosing a small "glazed conservatory", this solution allow patients moving in different ways rather than long and bored corridors. Also the free and open" atmosphere in this design; had a role in encouraging patients to participate and interact, keeping at the same time their personal space, which is a positive step in their recovery journey (14). White Architects has made a comfortable and inviting environment. Nature significantly affects the facility in a positive way health and well-being.

Figure 3. Every room offers views to the world outside. Ref. (14)

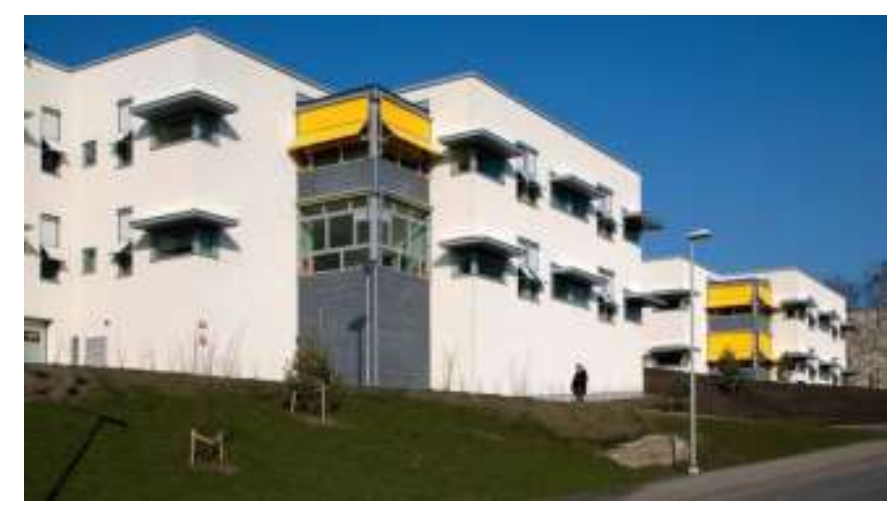

As (16) indicated the design of the hospital applied some biophilic patterns as follows:

\section{Nature inside space:}


- Visual Connection with Nature: the three garden in the center allow all the rooms to have a view, and make a direct and visual connection between patients and nature.

- Dynamic \& Diffuse Light: the garden inside the building brought natural daylight to the inner space.

\section{Presenting nature:}

- Complexity \& Order: it appeared in the repetition of the "L-shaped" pattern.

\section{Spatial characteristics:}

- Refuge: seats like trees out of the way in the yards of the garden; private nested to public spaces within the departments.

The application of the biophysical patterns of White Architects has provided the following benefits for the health and well-being of passengers:

- Visual Connection with Nature: lower blood pressure and heart rate. The participation, attention, and attitude are positively affected and patient were happy in general.

- Dynamic and Diffuse Light: the positive performance of the biological clock system is positively affected. Greater visual comfort.

- Complexity \& Order: positive responses affect sensory and physiological stress. The view were preferred.

- Refuge: improve how they concentrate and gives security feeling.

\section{Case Study: Khoo Teck Puat Hospital (KTPH), Singapore, 2010 (RMJM Architects)}

\subsection{Description of the Hospital}

KTPH is Singapore's Khoo Teck Puat Hospital; a 590-bed general and 10,957square-feet of greenery. This hospital win "Stephen R. Kellert Biophilic Design Award" Dec. 2017. The hospital is designed to add a tropical jungle environment with a waterfall that flows in a green courtyard in the center. Green roofs, flower boxes and exterior pavilion add also to the greenery of the hospital. The façade is contains windshields that help the wind direction to enter into the public areas of the hospital. The sunlight is directly blocked. The hospital's energy consumption has been minimized by $33 \%$ than the other traditional hospitals (17). 
Figure 4. Khoo Teck Puat Hospital (KTPH). Ref. (16)

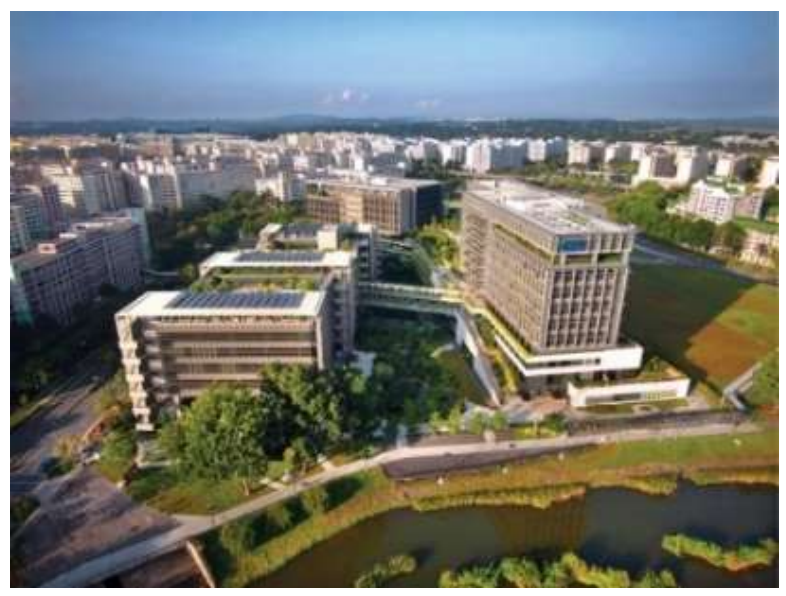

The vegetation consumes approximately four times more land than the green earth, which gives the hospital the same quality as the rainforests. The hospital was built in a V-shape so that skiers can ski first on the rainwater pool adjacent to the site. In the middle there is a playground that looks like a forest with evergreen vegetation at the highest levels of the building, which gives nature to the sick family. For the architect Steven Kieran, the hospital is demonstrating the key role that this approach can play in improving health (13). The blue and green areas represent $18 \%$. In post-occupation measurements, the local climate of this field was $2^{\circ} \mathrm{C}$ colder than the areas directly outside the hospital.

Khoo Teck Puat overlooks the picturesque Yishun Pond Park and is designed to be "patient-friendly". Along the walls of the building there are fins to guide the "prevailing north-east winds" to enter inside. Shading devices are used prevent direct "glare of sunlight". The devices also help enhancing brightness and saving energy by redirection of light towards the ceiling. "Solar panels" are used on the hospital's roof to operate large fans in the public area. "The air conditioning system" is designed to reduce "cooling loads" by drawing the cool air out of the "internal courtyards" (5). To sum up, this hospital offers a therapeutic environment through its appeal to the senses, from the viewing landscape scenes, abundant green landscapes hearing the water falling and smelling different plants' smells.

\subsection{Application of Biophilic patterns}

The following is the application of biophilic patterns on Khoo Teck Puat Hospital

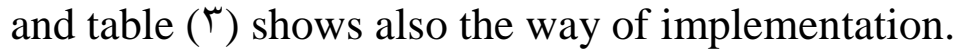

Table r. Implementation of biopilic patterns in Khoo Teck Puat Hospital, Ref, (Author; $16 ; 18)$ 


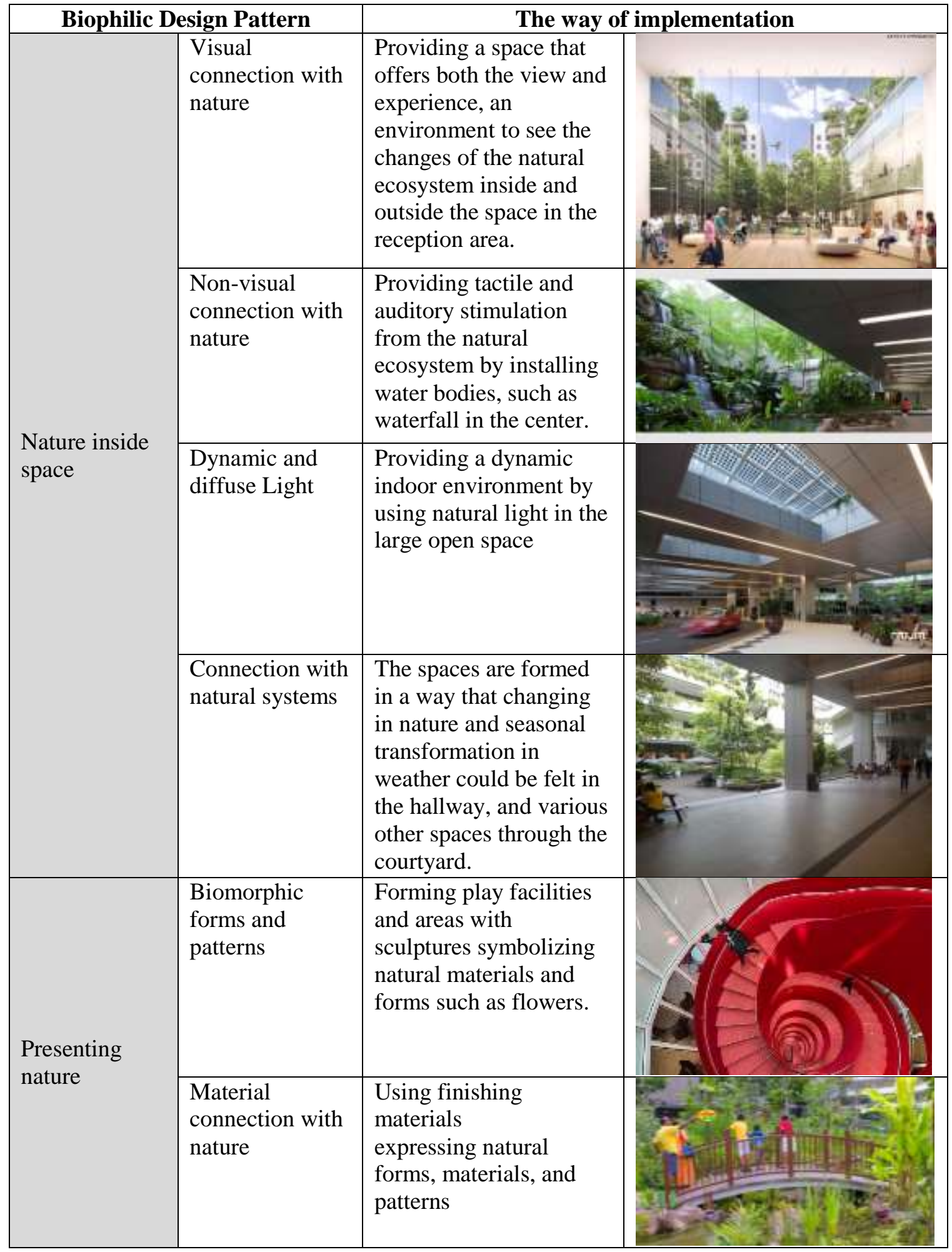




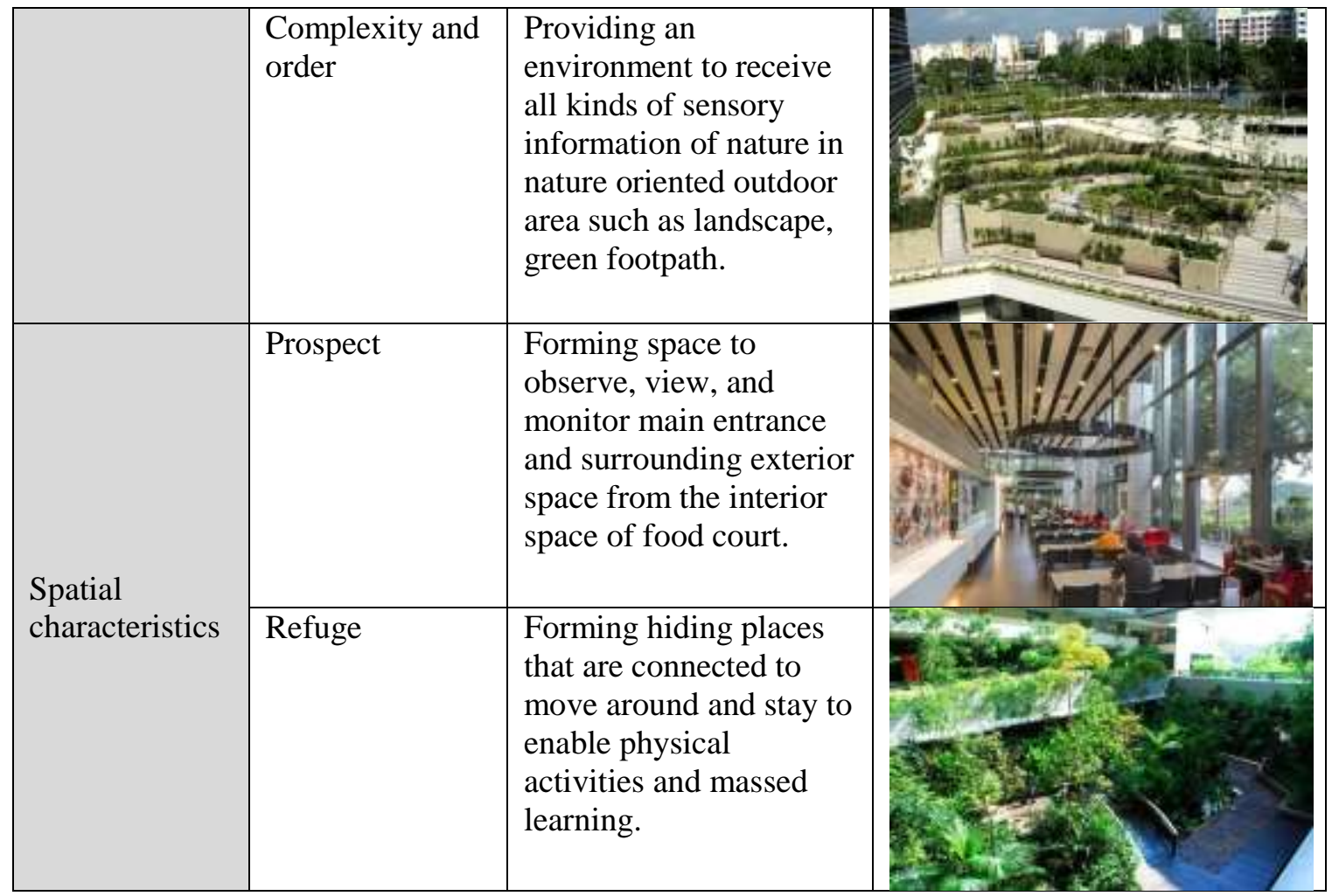

\section{Conclusions}

From this study the following conclusions could be drawn:

1. Biophilic design in a simple term; is the connection between human and nature. This connection makes human feel comfort, enjoy ant test aesthetics and activate human relationships. In this sense, incorporating biophilic design in health care environments could help patients in their healing process from different diseases.

2. Using biophilic design in hospitals' architecture, is not just using vegetation, plants, green roofs or walls; it is a holistic approach which needs a new way of thinking providing innovative solutions to integrate nature in hospitals environments.

3. It is not necessary for the design to contain all of the biophilic design patterns to be biophilic.

4. The role that can be played by architects in this matter is not easy, but requires much study and investigation of the relationship between human and nature.

\section{Recommendations}


1. Biophilic design could be adopted in the hot arid countries regions, especially Egypt, where the courtyard can contribute successfully to this type of design, especially in children' hospitals.

2. A checklist of appropriate plants could be developed in terms of environment and economics in order to achieve a biophilic efficient design.

3. Conduct more extensive and deep studies to reach the most suitable environmental solutions for the Egyptian environment.

4. Holding competitions at the level of the republic to come up with new solutions and ideas that apply the principles of biophilic design and fit to the society and the Egyptian environment.

\section{References}

1. Rytzell, H., (2018). Mother Nature Takes A Peek into Medical Facilities. Retrieved fromhttps://medium.com/the-healthy-city/mother-nature-takes-apeek-into-medical-facilities-f62d4b76c6c9

2. Totaforti, S., (2018). Applying The Benefits of Biophilic Theory to Hospital Design, City Territory and Architecture, 5:1, https://doi.org/10.1186/s40410-018-0077-5.

3. Chen, Y. (2017). The Impact of Biophilic on Health and Wellbeing of Residents through raising Environmental Awareness and Nature Connecteedness. Master of Landscape Architecture. Athens, Georgia.

4. Salingaros, Nicos A., (2015). Biophilia and Healing Environments: Healthy Principles for Designing the Built World. New York: Terrapin Bright Green, LLC.

5. Fromm, E., (1973), the Anatomy of Human Destructiveness, Holt, Rinehart and Winston, New York.

6. Wilson, E, O., (1984). Biophila, the Human Bond with Other Species. Harvard University Press, Cambridge, Massachusetts.

7. Rogers, K., (2019), Biophilia hypothesis. Retrieved from https://www.britannica.com/science/biophilia-hypothesis

8. Kellert, Stephen, R. et.al. (2008), Biophilic Design: the Theory, Science, and Practice of Bringing Buildings to Life. John Wiley.

9. Browning, B., (2018). Biophilic Design, More Than Just Plants. Retrieved from https://www.terrapinbrightgreen.com/blog/2018/09/biophilic-designjust-plants/

10. Huisman, E., et.al. (2012). Healing environment: A review of the impact of physical environmental factors on users. Building and Environment. https://doi.org/10.1016/j.buildenv.2012.06.016 
11. Browning, W.D., et.al. (2014). Biophilic design patterns: Emerging naturebased parameters for health and well-being in the built environment. ArchNet-IJAR 2014, 8, 62-76.

12. Park, Sung, J., Lee, Hyo, C., (2019). Spatial Design of Childcare Facilities Based on Biophilic Design Patterns. Sustainability 2019, 11, 2851; doi: 10.3390/su11102851

13. Walker, D., (2017). Two New Biophilic Design Case Studies. Retrieved from https://www.terrapinbrightgreen.com/blog/2017/12/two-newbiophilic-design-case-studies/

14. Lundin, S., (2017), Östra Hospital, EmergencyPsychiatryWard. Retrieved from https://whitearkitekter.com/project/ostra-hospital-emergencypsychiatry-ward/

15. Kishnani, N., (2017) Singapore's Khoo Teck Puat Hospital: Biophilic Design in Action, Retrieved from https://blog.interface.com/khoo-teckpuat-hospital-singapore-biophilic-design/

16. Nestor, C., (2017). Ostra Hospital, Psychiatric Facility. Ostra Hospital, White Architects, Göteborg, Swedlenc, Terrapin Bright Green.

17. Neal, G., (2018). A New Remedy: Introducing Biophilic Design into Hospitals. Retrieved from http://hconews.com/2018/01/31/a-new-remedyintroducing-biophilic-design-into-hospitals/

18. https://wallflower.com.sg/ 